\title{
Developing Islamic Suggestopedia-Based Classroom Management At Islamic Boarding Schools In Lampung Province
}

\author{
Muhamad Dini Handoko ${ }^{*}$, Idham Kholid ${ }^{2}$, Muhammad Ihsan Dacholfany ${ }^{3}$, Ida \\ Umami $^{4}$, Siti Patimah ${ }^{5}$, Koderi ${ }^{6}$, Jamal Fahri ${ }^{7}$,Yunita Wildaniati ${ }^{8}$ \\ ${ }^{1}$ Students in the Islamic Education Management Doctoral study program, Universitas Islam Negeri \\ Raden Intan Lampung, Indonesia. \\ ${ }^{2}$ Doctor of Islamic Education Management Study Program, UIN Raden Intan, Lampung, Indonesia \\ ${ }^{3}$ Islamic Religious Education Study Program, Faculty of Islamic Religion, Universitas \\ Muhammadiyah Metro-Lampung, Indonesia. \\ ${ }^{4}$ Islamic Religious Education Master Program, Institut Agama Islam Negeri Metro-Lampung, \\ Lampung, Indonesia. \\ ${ }^{5}$ Doctor of Islamic Education Management Study Program, UIN Raden Intan, Lampung, Indonesia \\ ${ }^{6}$ Arabic Language Education Study Program, Faculty of Tarbiyah and Teacher Training, Universitas \\ Islam Negeri Raden Intan Lampung, Indonesia. \\ ${ }^{7}$ Doctor of Islamic Education Management Study Program, UIN Raden Intan, Lampung, Indonesia \\ ${ }^{8}$ Madrasah Ibtidaiyah Teacher Education Study Program, Faculty of Tarbiyah and Teacher Training, \\ Institut Agama Islam Negeri Metro-Lampung, Indonesia.
}

Article History: Received: 10 November 2020; Revised 12 January 2021 Accepted: 27 January 2021; Published online: 5 April 2021

\begin{abstract}
This research was conducted at a boarding school in Lampung. The research object consisted of three Islamic boarding schools: Al-Ismailiyun Islamic Boarding School, South Lampung, Darul 'Ulya Kota Metro Islamic Boarding School, and Riyadlatul 'Ulum Islamic Boarding School, East Lampung. In general, this research aimed to analyze, validate, and test the effectiveness of class management in Islamic boarding schools in Lampung province. The approach applied in this research was development research using the ADDIE model. This research was a classroom management development research based on Islamic suggestopedia. The results revealed several important findings regarding classroom management in Islamic boarding schools in Lampung province. First is the condition of Class Management which has been applied in Islamic boarding schools. The second is the finding of a form of Islamic Suggestopedia-based Class Management which can increase the learning effectiveness at Islamic boarding schools in Lampung Province. The third is the result of implementing Islamic Suggestopedia-based Class Management which can increase the learning effectiveness at Islamic boarding schools in Lampung Province.
\end{abstract}

Keywords: Class Management, Islamic Suggestopedia, Islamic Boarding School

\section{A. Introduction}

Classroom management can be defined as the teacher's ability to utilize the potential of the class in the form of providing the opportunity as much as possible for each individual to carry out creative and directed activities. The scope of Class Management consists of organizing the physical design of the classroom, establishing rules and routines, developing caring relationships, implementing attractive and effective instruction, and overcoming disciplinary problems. In Classroom Management, not only the learning process is considered, but the factors that influence it must also be considered. These factors can be in the form of 
teacher factors as delivery of subject matter and student factors as parties who will receive lessons, as well as classroom environmental factors.

The basic concept that needs to be considered in classroom management is the placement of individuals, groups, schools and environmental factors that influence them. Teacher duties in classroom management such as controlling, regulating or disciplining students are actions that are less relevant at this time. The most important teacher activity at this time is managing, organizing and coordinating all student activities to achieve learning goals. In managing the classroom, the skills that teachers must possess include the ability to decide, understand, diagnose, and act towards improving the classroom atmosphere on aspects of Class Management. The aspects that need to be considered in Class Management are the nature of the class, driving force of class, classroom situations, selective and creative action.

S.A. Coetze describes in his book that when a teacher manages a class, he organizes himself. Therefore, there is a concept in classroom management that the class and the teacher all support and interact with each other. According to James Levin, it is stated that teaching and influencing students are two inseparable things. This is because there are elements to influence students when teaching is carried out. Thus, the basic concept of Class Management is the arrangement of teachers, students, and classes in the learning process.

E.C. Wragg mentions in his book that there are two points in the definition of classroom management, namely: what a teacher does to teach students and how. From this theory, it is illustrated that classroom management is the role of the teacher in the classroom and how it interacts with students in the classroom. By increasing their abilities, a teacher will be able to improve the quality of class management so that the teaching and learning process is comfortable and in accordance with their goals.

According to Mulyasa, Class Management is a skill possessed by teachers to create a conducive learning climate and control it in case of disruption in learning. Another case with Nawawi who stated that Class Management is the ability of the teacher to utilize the potential of the class in the form of providing the widest possible opportunity for each individual to carry out creative and directed activities. Fitri Oviyanti on the other hand argues that, "Class management is an effort to maximize the potential of the class in order to create a conducive atmosphere for students to learn where the teacher also feels comfortable in teaching".

Based on the above opinion, it can be concluded that Class Management is a relationship between the roles and interactions of teachers, students and their environment in the classroom so as to create a comfortable learning atmosphere.

Reviewing the importance of Class Management in a learning process, the author in this case will discuss what kind of Class Management model is suitable to be applied in the world of education. Several models try to be further reviewed in this study so that a Class Management method is obtained that seeks to provide learning comfort for students. This model is the Suggestopedia method.

The Suggestopedia method was developed by a Bulgarian education expert named Georgi Lozanov. Apart from being an educational expert, he is also an expert in the field of medical therapists and researchers. Suggestopedia is defined as a second language learning method that focuses on improving the learning process by providing a comfortable learning environment for students. Suggestopedia combines yoga relaxation, verbal suggestion and direct method. Suggestopedia provides a comfortable classroom environment where there are cases where music is the medium. The music used is classical type music that is comfortable to hear so that it is hoped that the learning process can run effectively and efficiently.

However, the Suggestopedia method also has weaknesses to be applied in the classroom. One of them is the use of hypnosis in learning. Not all teachers are able to use and have the knowledge of hypnosis. Therefore, the author in this case offers an Islamic Suggestopedia method which is deemed more suitable to be applied in Islamic boarding schools in Indonesia. 
Another thing that also underlies the selection of the Suggestopedia method is the Ministry of Education and Culture Regulation Number 23 of 2017. The regulation explains that full day school means that school days must last 8 hours per day, from Monday to Friday starting at $06.45-15.30 \mathrm{WIB}$, with a rest duration every two hours. The duration of the Teaching and Learning Activities is also in accordance with the 2013 curriculum.

The current full day school program still leaves many problems. This program was first launched by Minister Muhadjir Effendi in the 2017/2018 school year. Students are given a portion of studying longer at school so that they will come home later until the afternoon. From the Mojok.com site, students complain about teachers feeling spoiled in class. The teacher only divides the groups and then gives assignments through student worksheets (LKS). Even though when this program was rolled out, schools should be able to create comfortable learning conditions in the classroom where teachers must be able to manage the class well.

Information on the cnnindonesia.com site states that the full day school/pesantren program in Langkat, North Sumatra in 2019 is still experiencing several problems. The site explains that the escape of one of the students at one of the Islamic Boarding Schools there was because the teacher had done something abnormal. This incident, of course, was beyond the cottage's supervision. Meanwhile, on the site sindonews.com, it was reported that one of the students at the Pondok Pesantren Middle School in Bima, NTB had fled from the boarding school and did not want to go back to studying at the Islamic boarding school. In the same year, tribunnews.com also reported that a student had escaped from a boarding school in the Tulungagung area. In this case, the student was allegedly forced by two men who wanted to help her to escape.

Based on this problem, then the question arises whether the full day school program is the same as the program implemented in Islamic boarding schools. From the author's preliminary observations, there is a boarding school in Lampung Province that implements a full day school program. The two programs actually have the same meaning, namely a longer learning process in the classroom so that a good Class Management method is needed so that students have their pleasure while studying in schools/Islamic boarding schools. On the id.quora.com site, several factors that make students run away from the hut are mentioned: homesick, uncomfortable, bored with routines, wanting to go for refreshing and traveling, going to internet cafes, dating, cheap thrill, and roleplaying prison breaks. All of these problems can actually be resolved if the boarding school applies good Class Management. Although it is not presumed that all Islamic Boarding School have bad Class Management, however, there may be some of them that need to improve the quality of their Class Management.

\section{B. Research Methodology}

The type of research used in this research was Research and Development (R \& D). Akker stated that development studies are validation studies that aim to solve educational problems by using relevant theoretical knowledge. In addition, Sugiono stated that R \& D is a research method for producing certain products and examining products. In development research that only uses classes in the process, the most representative ADDIE model is widely used. The model describes the main processes which include Analyst (plan), Design, Development, Implementation, and Evaluation. Each of these processes is repeated at least 3 times.

Researchers conducted research and development of Islamic Suggestopedia-based Classroom Management in Islamic boarding schools in Lampung Province. The feasibility level of this model is known through validation by material experts, management experts, and educational scientists. In this case, development research based on qualitative data aims to test 
the level of user needs. This is done because according to the analysis of the existing problems of the users, in this case SMP / MTs students, need good Class Management.

This study focuses on three things, namely the condition of class management at the time before the study, the application of classroom management in limited trials, and the application of classroom management in broad trials. Researchers tested the validity of the data using content-related validity, which is lowering questions based on indicators that have been previously developed in the instrument lattice. Model development was done by using descriptive-quantitative analysis as a study of the results of observations. Statistical tests are also applied to see the results of the classroom management model trials that have been developed. The test used in development research was a formative test which consists of three tests, including: One-to-One Evaluation With Learner, Small-Group Evaluation, and Field Trial.

\section{Findings and Discussion}

The results of the preliminary needs analysis study carried out by researchers at three Islamic boarding schools in Lampung Province revealed that the Class Management process that has been implemented in Islamic boarding schools still has several things that should be of concern at a later date. These findings include: 1) In planning the lesson, namely by making lesson plans before teaching, it has been implemented properly by the teacher. However, these RPPs are only taken from existing RPPs without being developed to suit current needs; 2) There is still a teacher who does not use gadged in the learning process where the teacher only uses blackboards and markers as teaching aids; 3) Benches and tables in the classroom are still arranged in a row. The use of fragrances to create a more comfortable classroom atmosphere has also not been implemented; 4) Before teaching, a teacher also does not perform ablution. In addition, shalawat, murotal chanting, and prayer have not become a concern in the learning process so that the Islamic atmosphere in learning is still not very pronounced in the classroom. This should be a serious concern for all policy makers. A good classroom management will produce a good learning process which in turn will result in good learning achievement as well.

The feasibility test is carried out through an individual test (one to one expert) by a curriculum management expert. This test aims to see how feasible the existing model is to be applied in the world of education. The results of the expert feasibility test are presented in the following graph:

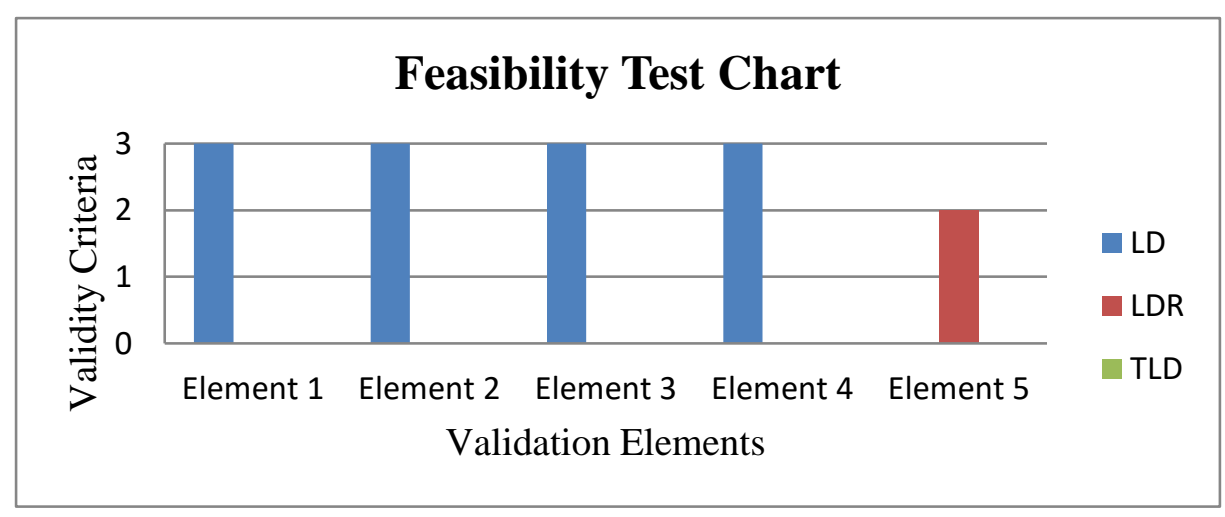

The graph above shows that of the five validation elements, four elements show the Eligible Model (EM), namely: method format,suitability of theory use in research methods, clarity of procedures, and steps in the classroom management process through the Islamic Suggestopedia method. There is only one element states that it is feasible to be used with revision, namely the element of using the Islamic method. 
Of all the trial processes at three Islamic boarding schools in Lampung Province, namely the Al-Ismailliyun Islamic Boarding School in South Lampung, the Daarul 'Ulya Islamic Boarding School in Metro City, and the Riyadlatul' Ulum Islamic Boarding School in East Lampung, a final model of the Class Management Method is obtained. It is used in SMP/MTs students in a boarding school with the following form:

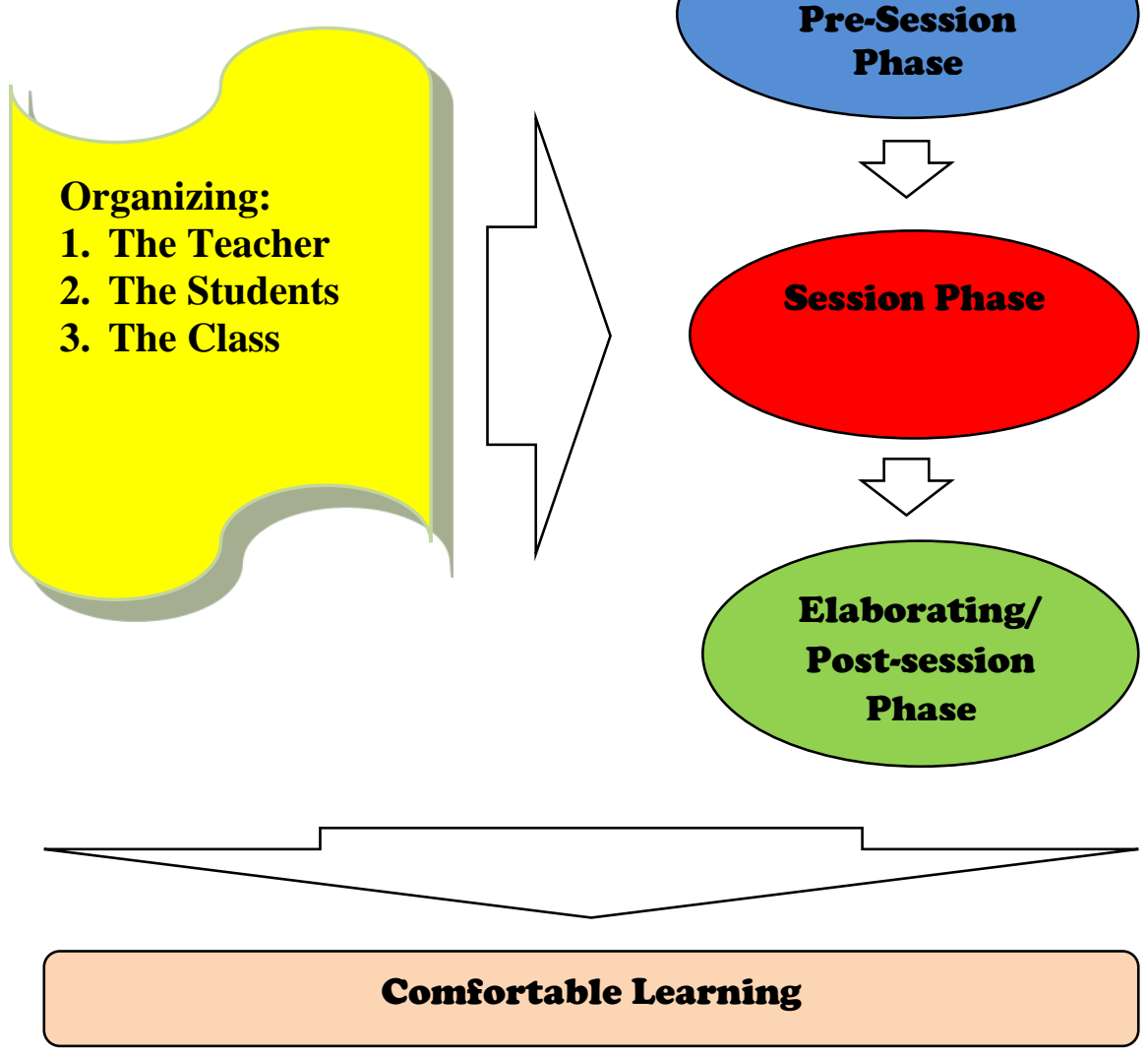

a. Steps Taken for Classroom Management Based on Islamic Suggestopedia

1) Teacher Organizing

a) Teachers must have a pure nature, namely by means of ablution and keeping clothes and attitudes clean. If the female teacher is unavailable, it is sufficient to maintain the cleanliness of clothes and attitudes.

b) Maintain manners so that students feel comfortable learning in the classroom by not speaking harshly and inappropriately.

c) Preparing Islamic material in learning since Islamic education is also charity education at the same time.

d) A teacher's dress does not have to be formal, but follows the existing rules.

e) Bring gadget and computer (portable computer).

f) Starting the class by saying greetings and giving words of motivation.

2) Student Organizing

a) Before studying, students must have a pure nature, by doing ablution when they leave the room at the Islamic boarding school, and maintaining the sanctity of 
clothes and attitudes. For female students who are unavailable, they only need to maintain the sanctity of their clothes and attitudes.

b) Students should honor their teacher and be humble or arrogant.

c) Always pray before studying.

d) Starting class by saying greetings

3) Class Organizing

a) Classrooms are made comfortable with Islamic themed writing, fragrances and floral decorations and portable audio speakers that do not have to be expensive, but are effective and efficient.

b) A recording of the recitation of the holy Koran (murotal) is provided.

c) Benches and desks in the classroom are arranged in a semicircle.

d) The number of students should be from 20 to 32 in the class.

4) Organizing the Learning Process

a) Fase Decoding/ Pre-sesion

1. Pray and then listen to a murotal about 10-15 minutes.

2. Giving the words motivation and praying

3. Presentation of new material (containing Islamic values).

b) Session Phase

This pahase is divided into active and passive parts

1. Active: discussion

2. Passive: the teacher restates the material

c) Elaborating phase

1. This is when the material is reviewed/re-reviewed by giving prizes to students who are able to answer or review existing material.

2. Listen to the recitation of the Koran (murotal) for about 10-15 minutes

\section{b. The Principles of Islamic Suggestopedia-Based Classroom Management}

1) Authority Purity. The teacher has the highest authority in the class to organize and deliver material. This also needs to be balanced by the teacher by maintaining the values of self-purity and attitude.

2) Infantilization. Classes in Class Management based on Islamic Suggestopedia are conditioned to be situations like a child.

3) Doubleplaneness. The application of Class Management based on Islamic Suggestopedia focuses on two aspects of learning consisting of the left brain and the right brain.

4) Intonation. In Management Classroom based on Islamic Suggestopedia, the teacher delivers the material slowly and repeatedly.

5) Al-Quran Rhytm. The chanting of the holy verses of the Koran is heard at the beginning of the decoding/pre-session phase and at the end of the elaborating/postsession phase in implementing Islamic Suggestopedia-based Class Management.

6) Pseudopassivenes. Students get more material from the teacher as they only receive material. Besides, students are also not given many tasks in the learning process. This is because this method will only reduce the affective level of students in the class.

c. Strengths and Weaknesses of Islamic Suggestopedia-Based Classroom Management

1) Strengths

a) The class is conditioned as comfortable as possible so that students and teachers feel comfortable in the classroom. Learning is not rigid with multiple 
assignments, dynamic seating arrangements, and the use of teacher clothes that are more relaxed but according to the rules.

b) Learning becomes a means of preaching for teachers, and a means of increasing Islam for students. In this case the knowledge of the world and the hereafter is achieved.

c) The use of modern but inexpensive learning media, because it is based on effectiveness and efficiency.

d) The material is more easily accepted by students, because it is conveyed with a slow and repetitive intonation.

e) Learning will be more blessed as it uses the holy verses of the Koran and salawat, thereby reducing boredom in studying.

f) The teacher is a source of knowledge that has high authority in regulating the material, so that the material will be easily controlled to avoid the entry of negative material, for example containing pornography, terrorism, and moral decadence.

2) Weaknesses

a) Infantilization learning, that is Class Management based on Islamic Suggestopedia, is conditioned into a situation like a child. There are some students who don't like being treated like this because they think they are adults.

b) Environmental limitations. In this regard, most schools have large classes of 30 to 40 students. One of the problems faced in utilizing this method is the number of students in the class so that if this method is applied in the class, the class used must also be larger in size than usual.

c) Its application can only be applied to Islamic-based schools because it uses some Islamic properties.

Based on a series of trials, starting from the main model trial, the first broad-scale trial, and the second broad-scale trial, the researchers finally found a final model that was ready to use. The Islamic Suggestopedia that has been tested has the following levels of effectiveness: 1) In the Limited Trial, the value obtained is the value of to $=4.152>t$ table $=2.086 ; 2$ ) In the First Area Trial, the value of to $=5.069>\mathrm{t}$ table $=2.086 ; 3$ ) In the Second Area Trial, the value of to $=4.694>\mathrm{t}$ table $=2.086$ is obtained. Therefore, it can be concluded that there is a significant difference between the mean of pre-test and post-test in each trial. It is shown that there is still an increase in the effectiveness of learning between before and after the Islamic Suggestopedia-based Class Management application in the classroom at each trial.

\section{Conclusion}

The findings from the results of limited trials and extensive trials indicated that Islamic Suggestopedia is able to improve the quality of Class Management. The existence of these differences can be concluded that the development of six principles of Suggestopedia Lozanov which includes Authority, Infantilization, Doubleplaneness, Intonation, Rhytm, and Pseudopassivenes into Authority and Purity, Infantilization, Doubleplaneness, Intonation, Al-Quran Rhytm, and Pseudopassivenes, can improve the quality of Class Management when implemented in Islamic boarding schools, namely through Islamic values and existing Islamic wisdom.

\section{References}

[1]. Akker, Jan Van Den. Educational Design Research. USA \& Canada: Routledge, 2006. 
[2]. Coetzee, SA et al. An Educator's Guide to effective Classroom Management. South Africa: Van Schaik Publisher, 2008.

[3]. Dick, Walter et al. The Systematic Design of Instruction. USA: Pearson Education Inc., 2015.

[4]. E.C. Wragg, Class Management in the Primary School, (London \& New York: Routledge, 2001).

[5]. Euis Karwati dan Donni Juni Priansa, Manajemen Kelas, (Bandung: Alfabeta, 2014).

[6]. Fitri Oviyanti, Pengelolaan Pengajaran, (Palembang: Rafa Press, 2009).

[7]. Garrett, Tracey. Effective Clasroom Management. New York and London: Teacher College Colombia University, 2014.

[8]. Gustafson, Kent L. Survey of Instructional Development Model. New York: ERIC. Syracuse University, 2002.

[9]. James Levin dan James F. Nolan, Principles of Classroom Management, (US: Pearson Education Inc., 2014).

[10]. Jan Van Den Akker, Educational Design Research, (USA \& Canada: Routledge, 2006).h.152Sugiyono, Metode Penelitian Kualitatif, Kuantitatif, dan R \& D, (Bandung: Alfabeta, 2014).

[11]. Karwati, Euis, dan Donni Juni Priansa. Manajemen Kelas. Bandung: Alfabeta, 2014.

[12]. Kent L. Gustafson, Survey of Instructional Development Model, (New York: ERIC. Syracuse University, 2002).

[13]. Levin, James, dan James F. Nolan. Principles of Classroom Management. US: Pearson Education Inc., 2014.

[14]. Magaji, Shehu et al. "Effect of 'Suggestopedia' Method on Senior Secondary School Student' Listening Skill in English Language in Ringim Jigawa". Fudma Journal of Education Foundation (FUJEF). Vol. 1 no. 1 (2018), hal. 121-28.

[15]. Oviyanti, Fitri. Pengelolaan Pengajaran. Palembang: Rafa Press, 2009.

[16]. SA Coetzee et al., An Educator's Guide to effective Classroom Management, (South Africa: Van Schaik Publisher, 2008).

[17]. Setiawan, J. A., Suparno, C. S., \& Tasrif, S. R. (2020). The Role of Parents on the Character Education of Kindergarten Children Aged 5-6 Years in Bima. Universal Journal of Educational Research, 8(3), 779-784.

[18]. Shehu Magaji et al., "Effect of 'Suggestopedia' Method on Senior Secondary School Student' Listening Skill in English Language in Ringim Jigawa", Fudma Journal of Education Foundation (FUJEF), Vol. 1 No. 1 (2018), hal. 121-28,

[19]. Sugiyono. Metode Penelitian Kualitatif, Kuantitatif, dan R \& D. Bandung: Alfabeta, 2014.

[20]. Tracey Garrett, Effective Clasroom Management, (New York and London: Teacher College Colombia University, 2014).

[21]. Walter Dick et al., The Systematic Design of Instruction, (USA: Pearson Education Inc., 2015).

[22]. Wihardjo, R. S. D., Nurani, Y., \& Ramadhan, S. (2020). The Comparison between the Effectiveness of Guided Discovery Model and Inquiry Model for Early Childhood Education Students. International Journal of Innovation, Creativity and Change, 11(3), 409-418.

[23]. Wragg, E.C. Class Management in the Primary School. London \& New York: Routledge, 2001. 